Review

\title{
Beneficial Effects of Leucine Supplementation on Criteria for Sarcopenia: A Systematic Review
}

\author{
Francisco M. Martínez-Arnau ${ }^{1,2}$ (D) Rosa Fonfría-Vivas ${ }^{2,3}$ and Omar Cauli $2,3, *$ (D) \\ 1 Department of Physiotherapy, University of Valencia, 46010 Valencia, Spain; francisco.m.martinez@uv.es \\ 2 Frailty and Cognitive Impairment Research Group (FROG), University of Valencia, 46010 Valencia, Spain; \\ rosa.fonfria@uv.es \\ 3 Department of Nursing, University of Valencia, 46010 Valencia, Spain \\ * Correspondence: Omar.Cauli@uv.es
}

Received: 9 September 2019; Accepted: 14 October 2019; Published: 17 October 2019

\begin{abstract}
Objective: Treating sarcopenia remains a challenge, and nutritional interventions present promising approaches. We summarize the effects of leucine supplementation in treating older individuals with sarcopenia associated with aging or to specific disorders, and we focus on the effect of leucine supplementation on various sarcopenia criteria, e.g., muscular strength, lean mass, and physical performance. Methods: A literature search for articles related to this topic was performed on the relevant databases, e.g., the PubMed/Medline, Embase, EBSCO, Cochrane, Lilacs, and Dialnet. The identified articles were reviewed according to Preferred Reporting Items for Systematic reviews and meta-analyses (PRISMA) guidelines. Results: Of the 163 articles we consulted, 23 met our inclusion criteria, analysing the effect of leucine or leucine-enriched protein in the treatment of sarcopenia, and 13 of these studies were based on randomized and placebo-controlled trials (RCTs). In overall terms, the published results show that administration of leucine or leucine-enriched proteins (range 1.2-6 g leucine/day) is well-tolerated and significantly improves sarcopenia in elderly individuals, mainly by improving lean muscle-mass content and in this case most protocols also include vitamin $\mathrm{D}$ co-administration. The effect of muscular strength showed mix results, and the effect on physical performance has seldom been studied. For sarcopenia-associated with specific disorders, the most promising effects of leucine supplementation are reported for the rehabilitation of post-stroke patients and in those with liver cirrhosis. Further placebo-controlled trials will be necessary to determine the effects of leucine and to evaluate sarcopenia with the criteria recommended by official Working Groups, thereby limiting the variability of methodological issues for sarcopenia measurement across studies.
\end{abstract}

Keywords: leucine; sarcopenia; muscular mass; muscular strength; elderly

\section{Introduction}

Sarcopenia is defined as a progressive loss of muscle mass, strength, and function [1,2]. From a physiological point view, sarcopenia starts in the fifth decade of life and at a population level, proceeds at a rate of $\sim 0.8 \%$ annually. In fact, the decrease in skeletal muscle strength induced by sarcopenia, known as dynapenia, is even more precipitous, occurring at an annual rate of $\sim 2-3 \%[2,3]$ and it is estimated that more than $20 \%$ of adults aged over 65 years, and over $50 \%$ of those aged at least 80 years are sarcopenic [4]. In some pathological conditions such as liver cirrhosis [5], chronic obstructive pulmonary disease [6,7], and diabetes [8], sarcopenia can appear earlier and its progression occurs more quickly. Several studies report that the most sarcopenic individuals are at an increased risk of developing severe sarcopenia-related complications, such as an increased risk of falls $[9,10]$, frailty [11], 
disability [12], and type-II diabetes [13,14], which all have a negative impact on their quality of life and premature mortality.

Within the framework of the Third National Health and Nutrition Examination Survey, Srikanthan and Karlamangla [12] have demonstrated that muscle mass is a predictor of longevity when taking into account the all-cause mortality in North American adults (aged over 55 or 65 years for men and women, respectively). One of the main ways in which sarcopenia contributes to the disease is that it alters muscular turnover and metabolism $[15,16]$. Moreover, older adults exhibit a decreased anabolic response to protein feeding $[17,18]$, which is a mechanism underpinning the loss of muscle mass in sarcopenic individuals. Compared to younger adults, those aged over 65 years required $\sim 70 \%$ more protein per meal to maximally stimulate muscle protein synthesis [19]. Furthermore, at a global level, only $40 \%$ of older adults meet the recommended daily allowance for protein $\left(0.8 \mathrm{~g} \cdot \mathrm{kg}-1 \cdot \mathrm{d}^{-1}\right)$ and $10 \%$ of older women do not even meet the estimated average requirement of $0.66 \mathrm{~g}$ protein $\cdot \mathrm{kg}^{-1} \cdot \mathrm{d}^{-1}[20,21]$.

One strategy to increase the muscle protein synthesis that has been investigated is the supplementation of diets with leucine, an essential branched-chain amino acid with important regulatory actions in muscles, which are at least partially mediated by the mammalian target of the rapamycin pathway [22]. Leucine modifies protein turnover in skeletal muscles, by decreasing proteolysis and by increasing protein synthesis. Physiological research reports have shown that leucine can enhance muscle protein-synthesis [23-26]. Furthermore, leucine can stimulate insulin release by pancreatic cells [27], showing that besides its beneficial effect in enhancing skeletal muscle glucose uptake, it is also an important anabolic signal in skeletal muscle.

Based on the above, administration of leucine-containing supplements is therefore a promising approach for treating sarcopenia. We took a systematic approach to analysing the current scientific evidence in this area, and to ascertaining whether the administration of leucine-containing supplements is effective in the treatment of sarcopenia. We also included interventions that used whey protein as a supplement, because these contain large amounts of leucine (approximately $13 \mathrm{~g}$ leucine/100 $\mathrm{g}$ protein [28]) and the consumption of whey protein appears to be the most effective at increasing muscle protein synthesis [29].

As a result, the main objectives of the systematic review were to (1) analyse the effects of administration of oral leucine supplements, alone or in combination with other supplements, on sarcopenia criteria, e.g., muscular mass, strength, and functional activity in older individuals; (2) evaluate the optimal leucine supplement delivery method, dose, and treatment duration in these populations; (3) identify which signs of sarcopenia most improved upon leucine supplementation; and (4) investigate the effects of leucine supplementation on secondary outcomes such as the parameters included in the integrative psychogeriatric evaluation instruments (i.e., cognitive function, ability to perform basic activities of life, mood, and quality of life).

\section{Materials and Methods}

This study was designed and developed according to the preferred reporting items for systematic reviews and meta-analysis (PRISMA) [30] guidelines, an evidence-based set of minimum items for assessing the benefits and harms of a given healthcare intervention.

\subsection{Literature Search}

We searched the literature in various electronic bibliographic databases (PubMed/Medline, Embase, EBSCO, Cochrane databases, Lilacs, and Dialnet) for all entries up until 30 March 2019, without applying any publication age limitations. The reference lists of all the relevant articles were manually cross-referenced in order to identify any additional articles. The primary search terms used for all six databases were 'leucine' and 'sarcopenia', as well as one of the following terms: 'older', 'elderly', 'disease' or 'trial'. 


\subsection{Inclusion and Exclusion Criteria}

To answer our research questions, we applied the following inclusion criteria to each of the considered manuscripts: (1) It was acknowledged as an original article; we included experimental studies (randomised and placebo-controlled trials) and observational studies (cohort, cross-sectional, and case-control studies); (2) it was a full text published either in English, Portuguese, or Spanish; (3) at least one of the sarcopenia criteria was measured: Muscular mass and/or muscular strength and/or physical performance; (4) a description of how sarcopenia was evaluated was defined in the methods section; (5) the concentration of leucine used in the intervention was specified or could be calculated. Studies performed in animals, case-report studies, letters to the Editor, abstracts from conferences, books, PhD theses were excluded.

\subsection{Data Collection and Analysis}

Details of the manuscripts identified in the literature search were uploaded into a web-based system, which was used to manage the screening process and remove any duplicate citations. In order to determine which studies would be included, three members of the review team independently screened the titles and abstracts of these articles and the full texts were retrieved based on our inclusion and exclusion criteria. Two reviewers independently extracted the following data from each article: The country in which the study was conducted, number of participants, age of the participants at the time of inclusion, sex of the participants, amount of leucine administered, co-administration of other substances, sarcopenia evaluation methods, and the main and secondary outcomes of the study. Any disagreement between the reviewers regarding the papers and data extracted from them was resolved by the third author.

\subsection{Assessment of Bias}

We assessed the risk of bias in each randomised and placebo-controlled study according to the Cochrane Review guidelines [31], which cover the following bias domains: Selection bias (random sequence generation and allocation concealment), performance bias (blinding of participants and personnel), detection bias (blinding the outcome assessment), attrition bias (incomplete outcome data), and reporting bias (selective reporting). The judgments were made independently by two researchers (FM-M-A and R-F-V), with any discrepancies resolved with the third author (OC).

\section{Results}

\subsection{Summary of Identified Publications}

Our search strategy identified 163 studies; after eliminating duplicates and applying inclusion criteria 23 were analysed to prepare the systematic review (Figure 1). Five of the studies [32-36] were not analysed in terms of the effects of sarcopenia criteria, since they were intended to study some molecular or physiological effects after short term exposure to leucine (one to six days). These studies basically investigated how short-term exposure to leucine supplementation increases anabolic pathway in the muscle by measuring the rate of protein synthesis after leucine supplementation [33-36]. Kemmler et al. [32] evaluated the effect of whole-body electromyostimulation with or without short-term exposure to leucine-enriched protein supplementation in community-dwelling older men with sarcopenic obesity.

Thirteen studies were based on RCTs and were included for further assessment of risk of bias according to the Cochrane Review guidelines [31]. Two researchers independently summarised the results extracted from these articles under the following four headings: (1) The effect of leucine supplementation on sarcopenia; (2) administration, dose, duration, and eventual side effects of leucine supplementation; (3) the effects of leucine supplementation on secondary outcomes. The main characteristics of studies and details of how they measured sarcopenia-related variables are summarised in Tables 1 and 2, respectively. 
Table 1. Main characteristics and measurement of three sarcopenia criteria in the analysed studies.

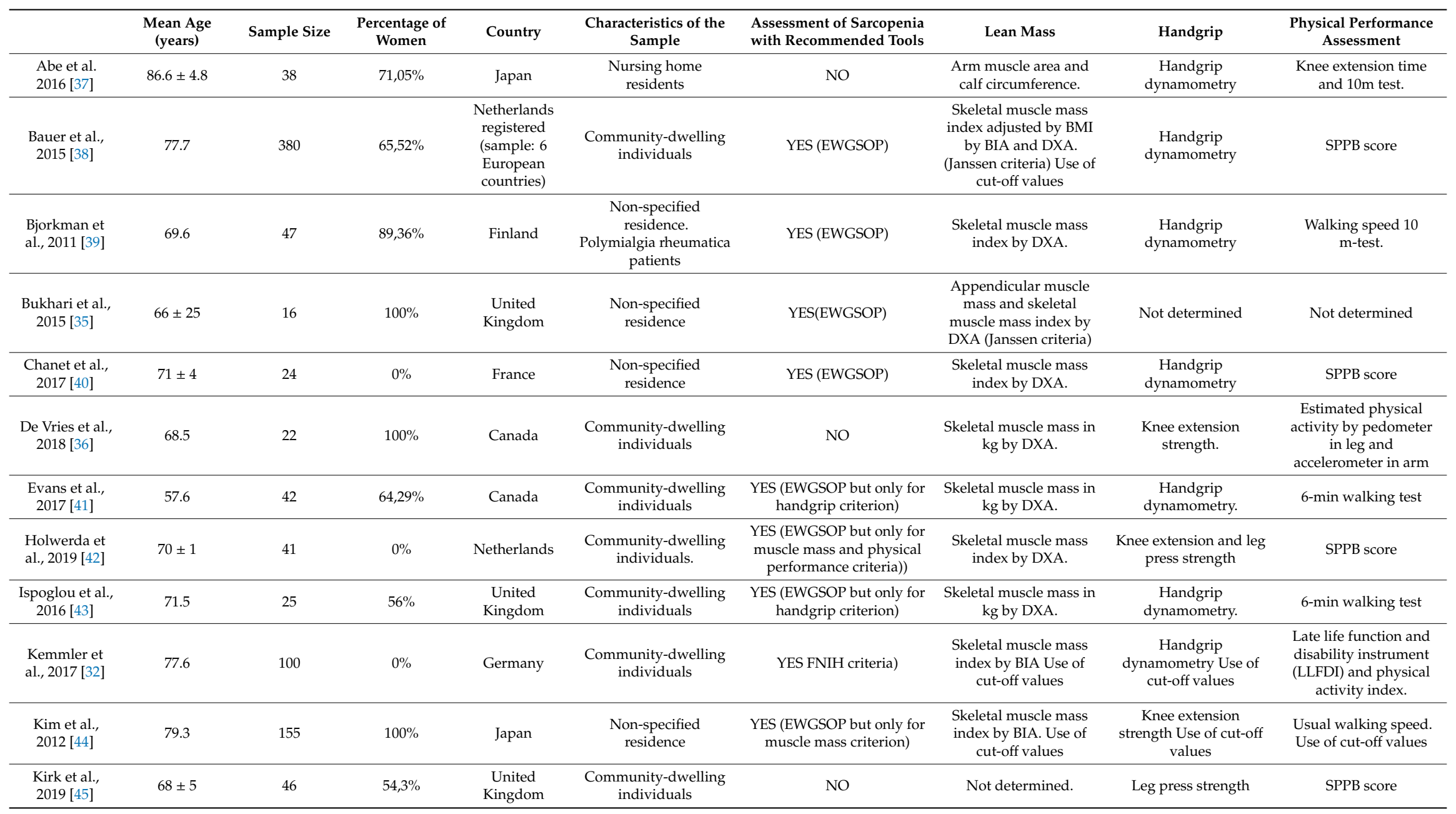


Table 1. Cont.

\begin{tabular}{|c|c|c|c|c|c|c|c|c|c|}
\hline & $\begin{array}{c}\text { Mean Age } \\
\text { (years) }\end{array}$ & Sample Size & $\begin{array}{l}\text { Percentage of } \\
\text { Women }\end{array}$ & Country & $\begin{array}{l}\text { Characteristics of the } \\
\text { Sample }\end{array}$ & $\begin{array}{l}\text { Assessment of Sarcopenia } \\
\text { with Recommended Tools }\end{array}$ & Lean Mass & Handgrip & $\begin{array}{c}\text { Physical Performance } \\
\text { Assessment }\end{array}$ \\
\hline $\begin{array}{l}\text { Kouw et al., } \\
2017[46]\end{array}$ & 71 & 48 & $0 \%$ & Netherlands & $\begin{array}{l}\text { Non-specified } \\
\text { residence }\end{array}$ & $\begin{array}{l}\text { YES (EWGSOP but only for } \\
\text { muscle mass criterion) }\end{array}$ & $\begin{array}{c}\text { Skeletal muscle mass } \\
\text { index by DXA. }\end{array}$ & Not determined & Not determined \\
\hline $\begin{array}{l}\text { Kramer et al., } \\
\quad 2017 \text { [33] }\end{array}$ & 75 & 30 & $0 \%$ & Netherlands & $\begin{array}{c}\text { Community-dwelling } \\
\text { individuals }\end{array}$ & YES (EWGSOP criteria) & $\begin{array}{l}\text { Skeletal muscle mass } \\
\text { index by DXA. Use of } \\
\text { cut-off values. }\end{array}$ & $\begin{array}{c}\text { Handgrip } \\
\text { dynamometry Use of } \\
\text { cut-off values }\end{array}$ & $\begin{array}{l}\text { Walking speed } 4 \mathrm{~m} \text {-test } \\
\text { Use of cut-off values }\end{array}$ \\
\hline $\begin{array}{l}\text { Dal Negro et } \\
\text { al., } 2012[47]\end{array}$ & 74.6 & 88 & $30,7 \%$ & Italy & $\begin{array}{l}\text { Community-dwelling } \\
\text { individuals. COPD } \\
\text { patients. }\end{array}$ & NO & $\begin{array}{l}\text { Skeletal muscle mass } \\
\text { index by BIA. } \\
\text { (Baarends criteria). Use } \\
\text { of cut-off values }\end{array}$ & $\begin{array}{l}\text { Handgrip } \\
\text { dynamometry }\end{array}$ & $\begin{array}{l}\text { Physical activity by } \\
\text { daily steps. }\end{array}$ \\
\hline $\begin{array}{l}\text { Rondanelli et } \\
\text { al., } 2016 \text { [48] }\end{array}$ & 80.3 & 130 & $59,23 \%$ & Italy & $\begin{array}{l}\text { Nursing home } \\
\text { residents }\end{array}$ & $\begin{array}{l}\text { YES (EWGSOP but only for } \\
\text { muscle mass criterion) }\end{array}$ & $\begin{array}{c}\text { Skeletal muscle mass } \\
\text { index by DXA Use of } \\
\text { cut-off values }\end{array}$ & $\begin{array}{l}\text { Handgrip } \\
\text { dynamometry }\end{array}$ & $\begin{array}{l}\text { Physical activity by } \\
\text { activities of daily living. }\end{array}$ \\
\hline $\begin{array}{l}\text { Soriano et al., } \\
2013 \text { [49] }\end{array}$ & 62 & 17 & $29,4 \%$ & Spain & $\begin{array}{l}\text { Non-specified } \\
\text { residence. Patients with } \\
\text { liver cirrhosis. }\end{array}$ & NO & $\begin{array}{l}\text { Arm muscle area and } \\
\text { quadriceps perimeter. }\end{array}$ & Not determined & 6-min walking test \\
\hline $\begin{array}{l}\text { Van den Bool } \\
\text { et al., 2017 [50] }\end{array}$ & 62.6 & 81 & $49 \%$ & Netherlands & $\begin{array}{l}\text { Community-dwelling } \\
\text { individuals. COPD } \\
\text { patients. }\end{array}$ & NO & $\begin{array}{l}\text { Skeletal muscle mass in } \\
\mathrm{kg} \text { by DXA. }\end{array}$ & $\begin{array}{l}\text { Knee extension } \\
\text { strength and } \\
\text { respiratory muscle } \\
\text { strength }\end{array}$ & 6-min walking test \\
\hline $\begin{array}{l}\text { Verhoeven et } \\
\text { al., } 2009 \text { [51] }\end{array}$ & $71 \pm 4$ & 30 & $0 \%$ & Netherlands & $\begin{array}{c}\text { Community-dwelling } \\
\text { individuals. }\end{array}$ & NO & $\begin{array}{l}\text { Skeletal muscle mass in } \\
\text { kg by DXA. }\end{array}$ & $\begin{array}{c}\text { Knee extension and leg } \\
\text { press strength. }\end{array}$ & Not determined \\
\hline $\begin{array}{l}\text { Verlaan et al., } \\
2018 \text { [52] }\end{array}$ & 77.7 & 380 & $65 \%$ & $\begin{array}{c}\text { Netherlands } \\
\text { registered } \\
\text { (multicenter } \\
\text { several } \\
\text { countries) (18 } \\
\text { centers) } \\
\end{array}$ & $\begin{array}{c}\text { Community-dwelling } \\
\text { individuals }\end{array}$ & $\begin{array}{l}\text { YES (EWGSOP but only for } \\
\text { muscle mass criterion) }\end{array}$ & $\begin{array}{l}\text { Skeletal muscle mass } \\
\text { index adjusted by BMI } \\
\text { by BIA (Janssen criteria) } \\
\text { Use of cut-off values }\end{array}$ & $\begin{array}{c}\text { Handgrip } \\
\text { dynamometry }\end{array}$ & SPPB score. \\
\hline $\begin{array}{c}\text { Verreijen et al., } \\
2015[53] \\
\end{array}$ & 63.4 & $80 \mathrm{I}(40) \mathrm{C}(40)$ & $53 \%$ & Netherlands & $\begin{array}{l}\text { Non-specified } \\
\text { residence }\end{array}$ & YES (EWGSOP) & $\begin{array}{l}\text { Skeletal muscle mass } \\
\text { index by DXA. }\end{array}$ & $\begin{array}{c}\text { Handgrip } \\
\text { dynamometry. }\end{array}$ & Walking speed $4 \mathrm{~m}$-test \\
\hline $\begin{array}{l}\text { Yoshimura et } \\
\text { al., } 2019 \text { [54] }\end{array}$ & 79.8 & 44 & $68.2 \%$ & Japan & $\begin{array}{l}\text { Non-specified } \\
\text { residence. Post-stroke } \\
\text { patients }\end{array}$ & YES (AWGS) & $\begin{array}{l}\text { Skeletal muscle mass } \\
\text { index by BIA Use of } \\
\text { cut-off values }\end{array}$ & $\begin{array}{l}\text { Handgrip } \\
\text { dynamometry Use of } \\
\text { cut-off values }\end{array}$ & FIM score \\
\hline
\end{tabular}

AWGS: Asian Working group for Sarcopenia; BIA: Bioelectrical impedance analysis; BMI: Body mass index; DXA: Dual X-ray absorptiometry; EWGSOP: European Working Group for

Sarcopenia in Older people; FIM: Functional independence measure; LLFDI: Late life function and disability instrument; SPPB: Short physical performance battery. 
Table 2. Characteristics of leucine and placebo administration and effects on the three sarcopenia criteria.

\begin{tabular}{|c|c|c|c|c|c|c|c|}
\hline & $\begin{array}{l}\text { Leucine Dose } \\
\text { (g/day) }\end{array}$ & $\begin{array}{l}\text { Additional Supplementation Intervention } \\
\text { Constituents (g/day) }\end{array}$ & Control Group & $\begin{array}{l}\text { Treatment } \\
\text { Duration }\end{array}$ & $\begin{array}{l}\text { Effect on Muscle } \\
\text { Strength }\end{array}$ & $\begin{array}{l}\text { Effect on Lean } \\
\text { Mass }\end{array}$ & $\begin{array}{l}\text { Effect on Walking } \\
\text { Speed }\end{array}$ \\
\hline Abe 2016 [37] & 1.2 & $\begin{array}{l}\text { Group 1: EAAs (3 g), vit-D (800IU), medium-chain TGs } \\
\text { (6 g); } \\
\begin{array}{r}\text { Group 2: EAAs (3 g), vit-D (800IU), or long-chain TGs (6 } \\
\text { g) }\end{array}\end{array}$ & No placebo group & 13 weeks & Improved & Not determined & Improved \\
\hline Bauer 2015 [38] & 6 & $\begin{array}{l}\text { Whey protein }(40 \mathrm{~g}) \text {, carbohydrates }(18 \mathrm{~g}) \text {, fat }(6 \mathrm{~g}) \text {, vit-D } \\
(1600 \mathrm{IU}) \text { and mixture of vitamins, minerals and fibers }\end{array}$ & $\begin{array}{c}\text { Isocaloric product without protein } \\
\text { content }\end{array}$ & 13 weeks & Not altered & Improved & Not altered \\
\hline Bjorkman 2011 [39] & $\begin{array}{l}19.2(\text { Group 1) or } \\
16.8(\text { Group 2) - } \\
\text { calculated }\end{array}$ & $\begin{array}{l}\text { Group 1: Whey protein }(160 \mathrm{~g}) \text { and casein }(40 \mathrm{~g}) \\
\text { Group 2: Whey protein }(40 \mathrm{~g}) \text { and casein }(160 \mathrm{~g})\end{array}$ & No placebo group & $\begin{array}{l}8 \text { weeks (and } \\
\text { crossover) }\end{array}$ & Decreased & Not altered & Improved \\
\hline Chanet 2017 [40] & 3 & $\begin{array}{l}\text { Protein }(21 \mathrm{~g}) \text {, carbohydrates }(9.5 \mathrm{~g}) \text {, fat }(3 \mathrm{~g}) \text {, vit-D ( } 20 \\
\mu \mathrm{g}) \text { and mixture of vitamins, minerals and fibers }\end{array}$ & Flavored watery placebo drink & 6 weeks & Not altered & Improved & Not altered \\
\hline Evans 2017 [41] & 2 (Group 1) & $\begin{array}{l}\text { Group 1: Leucine }(2 \mathrm{~g}), \mathrm{L}-\text {-Carnitine }(1.5 \mathrm{~g}) \text {, creatine } \\
\text { monohydrates }(3 \mathrm{~g}) \text {, Vit-D }(400 \mathrm{IU}) ; \\
\text { Group 2: L-Carnitine }(1,5 \mathrm{~g})\end{array}$ & Placebo dissolved in orange juice & 8 weeks & Not altered & $\begin{array}{l}\text { Improved (only in } \\
\text { Group 1) }\end{array}$ & Not determined \\
\hline $\begin{array}{c}\text { Holwerda } 2019 \\
{[42]}\end{array}$ & 2,8 (Group 1) & $\begin{array}{l}\text { Group 1: Whey protein (20,7 g, with } 2.8 \mathrm{~g} \text { leucine), } \\
\text { exercise (3 times/week) }\end{array}$ & $\begin{array}{l}\text { Isocaloric product without protein } \\
\text { content and exercise ( } 3 \text { times/week) }\end{array}$ & 12 weeks & Not altered & Not altered & Not altered \\
\hline Ispoglou 2016 [43] & $\begin{array}{l}3 \text { (Group 1) or } 6 \\
\quad \text { (Group 2) - } \\
\text { calculated }\end{array}$ & $\begin{array}{l}\text { Group 1: EAA mixture }(15 \mathrm{~g}) \\
\text { Group 2: EAA mixture leucine-enriched (15 g) }\end{array}$ & Isocaloric lactose placebo & 13 weeks & Not altered & $\begin{array}{l}\text { Improved (only in } \\
\text { group 2) }\end{array}$ & Not determined \\
\hline Kim 2012 [44] & 2.5 (Group 1 and 3 ) & $\begin{array}{l}\text { Group 1: EAA (6 g), exercise (2 times/week); } \\
\text { Group 2: Exercise (2 times/week); } \\
\text { Group 3: EAA (6 g);Group 4: Health education }\end{array}$ & Health education program & 13 weeks & $\begin{array}{c}\text { Improved } \\
\text { (only in Group1) }\end{array}$ & $\begin{array}{l}\text { Improved (only in } \\
\text { Group 1) }\end{array}$ & $\begin{array}{l}\text { Improved (in } \\
\text { Groups } 1 \text { and 2) }\end{array}$ \\
\hline Kirk 2019 [45] & 7 - estimated & $\begin{array}{c}\text { Group 1: Whey protein }(1,5 \mathrm{~g} / \mathrm{kg} / \text { day }) \text {, exercise }(3 \\
\text { times } / \text { week }) \\
\text { Group 2: Exercise (3 times/week) }\end{array}$ & No placebo group & 16 weeks & Not altered & Not determined & Not altered \\
\hline $\begin{array}{c}\text { Dal Negro } 2012 \\
{[47]}\end{array}$ & 2.5 & EAA $(8 \mathrm{~g})$ & $\begin{array}{l}\text { Isocaloric product without protein } \\
\text { content }\end{array}$ & 12 weeks & Improved & Not altered & Not determined \\
\hline Leenders 2011 [34] & 7.5 & Leucine alone & Wheat flour & 24 weeks & Not altered & Not altered & Not determined \\
\hline $\begin{array}{c}\text { Rondanelli } 2016 \\
{[48]}\end{array}$ & 4 & $\begin{array}{l}\text { Whey protein (32 g with } 10,9 \mathrm{~g} \text { of EAA), Vit-D (100IU), } \\
\text { exercise ( } 3 \text { times/week) }\end{array}$ & $\begin{array}{l}\text { Isocaloric maltodextrine placebo (32 } \\
\mathrm{g})\end{array}$ & 12 weeks & Improved & Improved & Not determined \\
\hline Soriano 2013 [49] & 10 & $\begin{array}{l}\text { Group 1: Leucine and nutritional assessment; } \\
\text { Group 2: Leucine, nutritional assessment and exercise }\end{array}$ & No placebo group & 13 weeks & Not determined & Not determined & Improved \\
\hline $\begin{array}{l}\text { Van de Bool } 2017 \\
\text { [50] }\end{array}$ & $\begin{array}{l}1.8 \text { or } 2.7- \\
\text { calculated }\end{array}$ & Protein (between 18.74 and $28.11 \mathrm{~g}$ ) & $\begin{array}{l}\text { Flavored non-caloric protein-free } \\
\text { aqueous placebo }\end{array}$ & 17 weeks & Not determined & Not altered & Not determined \\
\hline $\begin{array}{l}\text { Verhoeven } 2009 \\
{[51]}\end{array}$ & 7.5 & Leucine alone & Wheat flour & 12 weeks & Not altered & Not altered & Not determined \\
\hline Verlaan 2018 [52] & 6 & Whey protein (20 g), Vit-D (800 IU) & $\begin{array}{c}\text { Isocaloric product without protein } \\
\text { content }\end{array}$ & 13 weeks & Not determined & Improved & Not determined \\
\hline Verreijen 2015 [53] & 2,8 & $\begin{array}{l}\text { Whey protein (20.7 g with } 10.6 \mathrm{~g} \text { of EAA), vit-D (20 } \mu \mathrm{g}) \text {, } \\
\text { exercise ( } 3 \text { times/week) }\end{array}$ & $\begin{array}{l}\text { Isocaloric product without protein } \\
\text { content }\end{array}$ & 13 weeks & Not altered & Improved & Not determined \\
\hline $\begin{array}{c}\text { Yoshimura } 2019 \\
{[54]}\end{array}$ & 3 & $\begin{array}{l}\text { Group 1: EAA ( } 7.5 \mathrm{~g}), \text { exercise ( } 7 \text { times/week) } \\
\text { Group 2: Exercise ( } 7 \text { times/week) }\end{array}$ & No placebo group & 8 weeks & Improved & Improved & Not determined \\
\hline
\end{tabular}




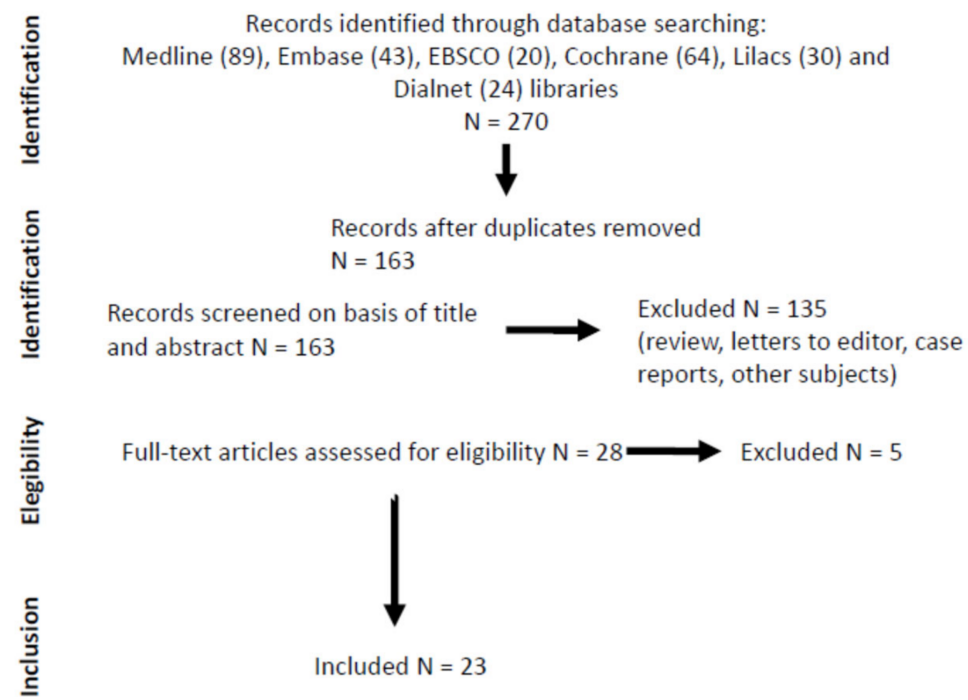

Figure 1. Preferred Reporting Items for Systematic reviews and meta-analyses (PRISMA) workflow for literature searches. Five of the studies [32-36] were not analysed in terms of the effects of sarcopenia criteria, since they were intended to study some molecular or physiological effects after short-term exposure to leucine (one to six days).

\subsection{Effect of Leucine Supplementation on Three Sarcopenia Criteria}

Three studies were performed in Japan, two in Canada, and the others in Europe; thirteen studies classified sarcopenic individuals based on one or more accepted criteria according to specific guidelines such as those proposed by the European Working Group on Sarcopenia in Older People (EWGSOP) [1] (Figure 2) or other working groups [32,54]. The remaining studies included in the review evaluated sarcopenia by other measurements without fulfilling specific guidelines, and/or did not use cut-off points to classify sarcopenic versus non-sarcopenic individuals (Table 1). The age range of the participants was 61-87 years, and most participants were community-dwelling adults or nursing home residents of either sex. However, several studies were performed only in men [32-34,40,42,46,51] or in women $[35,36,44]$.

The effects of leucine supplementation on the three sarcopenia criteria, i.e., muscle strength, lean mass, and physical performance (walking speed) are summarized in Table 2. Six of the 16 studies that evaluated muscular strength reported an improvement in muscle strength following leucine supplementation. One study found [39] a negative effect for these parameters. Neither co-supplementation with vitamin D (or other constituents) nor the leucine-administration route (among essential amino-acid (EAA) mixtures or as leucine-enriched protein preparations) had a clear effect on muscle strength gains induced by the supplementation. Ten of the 16 studies that evaluated the effect on lean mass found an improvement and all of the studies reporting co-supplementation with vitamin D had a beneficial effect on lean mass. However, some studies without vitamin D co-supplementation also showed some beneficial effects on this sarcopenia criterion [43,44]. Among the six studies that evaluated the effect on physical performance (operationalized by measuring the walking speed), three studies found a significant improvement after nutritional supplementation with leucine (with whey/casein protein or as part of an EAA mixture, with or without vitamin D).

Several studies used the 6-min walking test as a measure of low physical performance. However, even it is related to walking speed, this parameter cannot be used as a substitute for the EGSWOP criterion since the distance achieved during the 6 min walking test may be influenced by other parameters such as fatigue and cardiovascular and respiratory problems that could alter the results of the test. Other co-interventions including carnitine and creatine [41], and triglyceride (TG) [37] supplementation and electrostimulation [32] do not present more beneficial effects compared to the studies in which the nutritional intervention included leucine or whey protein with or without vitamin D. 
By contrast, the interventions that include a program of physical exercise $[44,48,49,53]$, co-administered with leucine-supplementation showed more positive effects than individuals performing physical exercise with no supplementation, or only receiving nutritional intervention.

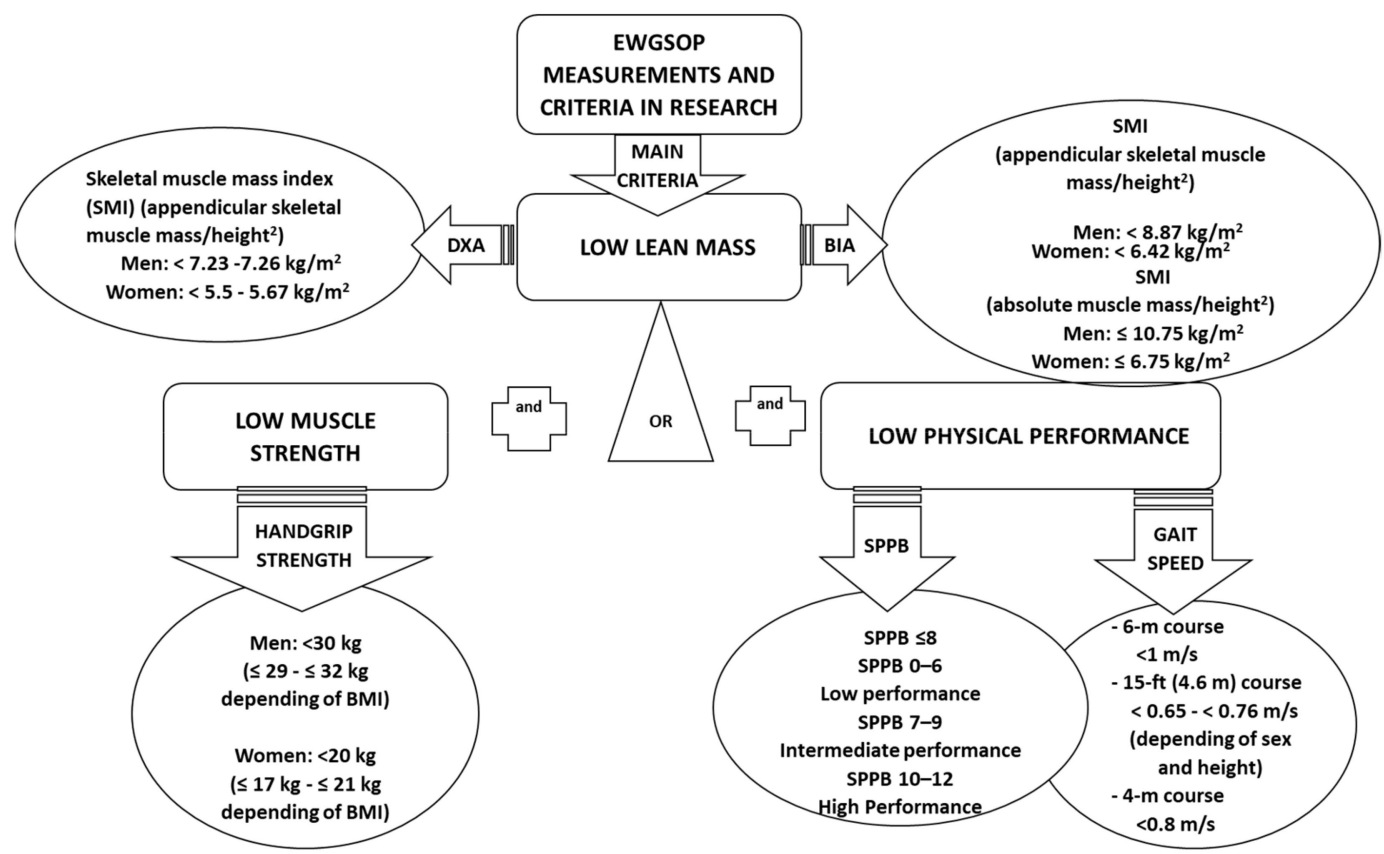

Figure 2. Sarcopenia criteria based on European Working Group on Sarcopenia in Older People (EWGSOP) guidelines.

As for the effect of leucine-supplementation in sarcopenia-associated disorders, clinical trials were performed on patients with chronic obstructive pulmonary disease (COPD) [47,50], liver cirrhosis [49], type II diabetes [34], polymialgia rheumatica [39], or post-stroke patients [54]. The effect of leucine supplementation on sarcopenia criteria were weaker or absent compared to those reported in studies that did not recruit individuals with a specific pathology. The beneficial effects included an improvement in muscle strength observed in COPD patients [47] and in muscle strength and lean mass content in post-stroke patients [54] and in physical performance in cirrhotic patients when co-administered with a physical exercise program [49].

\subsection{Administration, Dose, Duration, and Safety of Leucine Supplementation}

Leucine nutritional interventions were administered alone, in an EAA mixture, or in leucine-enriched whey/casein protein (Table 2) at a dose of 1.2-6 g/day, and in nine studies leucine was co-supplemented with 85-800 IU of vitamin D per day. Thirteen studies compared the results of the intervention group(s) with a placebo-controlled group. The duration of the nutritional interventions or experiments ranged from 1 day (acute effects) to 17 weeks. In three studies leucine-containing supplements were administered only once in order to study the acute molecular effects of leucine (Table 2). Depending on the dose, acute administration of EAA mixtures or whey/casein protein stimulates albumin [35] and muscle-protein synthesis, by $20 \%-50 \%$ in the latter case $[33,35,46]$; these anabolic effects occurred to a similar extent in both sarcopenic and non-sarcopenic individuals [33]. 
Most studies evaluated safety based on the absence or appearance of serious side effects (e.g., nausea, diarrhoea, or gastrointestinal tract complaints) associated with the supplementation. The supplementation's protocols tested in the studies were generally well tolerated, and none of the adverse events resulted in discontinuation of product consumption or study participation $[32,33,37,40,47,48]$. Only the study that used the highest dose of whey protein (160 g per day) reported some gastrointestinal complaints (early satiety, flatulence, nausea, and diarrhoea) in $48.9 \%$ of the sample [39].

\subsection{Analysis of Moderating Factors and Subgroups}

In the study by Verlaan et al. [52], appendicular muscle mass significantly increased after leucine supplementation in the individuals in the intervention group with both higher baseline protein intakes and $25(\mathrm{OH}) \mathrm{D}$ concentrations. Specifically, changes in the appendicular muscle to total body fat ratio after whey/casein protein supplementation were significant in patients aged over 69 years [39]. None of the studies involving both sexes tried to experimentally ascertain if there were any gender differences in muscle gain.

\subsection{The Effects of Leucine Supplementation on Secondary Outcomes}

As secondary outcomes, we evaluated the effect of leucine-containing supplements on other psychogeriatric evaluation parameters such as cognitive function, depression symptoms, the ability to perform activities of daily life, and quality of life. Several studies reported an improvement in cognitive functions with the administration of leucine, EAAs, or whey proteins alone [47-49] or with supplementation with EAAs, vitamin D, and TGs [37], although these effects may be because of the presence of the medium-chain TGs also included in the nutritional intervention used in this latter study. Rondanelli et al. [48] also reported that leucine supplementation improved patients' functional ability to perform the activities of daily life, and others showed an improvement in the symptoms of depression [50,52]. Finally, Bauer et al. and Dal Negro et al. [38,47], but not Evans et al. [41] reported an improvement in the quality of life scores among leucine-supplemented individuals.

\subsection{Bias Risk-Evaluation in Randomised Controlled Trials}

The evaluation of risk bias in randomised and placebo-controlled clinical trials (RCT) was performed using the Cochrane guidelines mentioned above [31] in order to analyse each bias type in the 13 RCTs. A summary of bias-risk in RCTs is shown in Table 3. With regard to the selection bias, random sequence generation was unclear or high in eight studies, whereas allocation concealment was high in only three RCTs. Performance bias was clearly avoided in all the trials except for one study, in which it was unclear if the blinding of the participants and personnel to the treatments was properly performed. Avoidance of detection bias, by blinding the researchers to the assessment outcomes, was the most unmet risk of bias, and it was clearly achieved in two studies [51,52] but not mentioned in the other reports. The presence of attrition bias resulting from the collection of incomplete outcome data, was unclear in six RCTs. Reporting bias, i.e., selective reporting, was unclear in five trials: They lacked some information related to secondary outcomes or socio-demographic factors. The RCTs with the lowest risk of bias were those reported in Bauer et al. [38] and Van de Bool [50], but from a general point of view all the RCTs selected have an acceptably low level risk of biases and they are suitable for making some recommendations (see below). 
Table 3. Assessment of risk of bias for randomized and placebo-controlled trials (RCTs).

\begin{tabular}{|c|c|c|c|c|c|c|}
\hline \multirow{2}{*}{$\begin{array}{c}\text { Bias Domain } \\
\text { Source of Bias }\end{array}$} & \multicolumn{2}{|c|}{ Selection Bias } & \multirow{3}{*}{$\begin{array}{c}\text { Performance Bias } \\
\text { Blinding of } \\
\text { Participants and } \\
\text { Personnel }\end{array}$} & \multirow{3}{*}{$\begin{array}{c}\text { Detection Bias } \\
\text { Blinding of } \\
\text { Outcome } \\
\text { Assessment }\end{array}$} & \multirow{3}{*}{$\begin{array}{c}\text { Attrition Bias } \\
\text { Incomplete } \\
\text { Outcome Data }\end{array}$} & \multirow{3}{*}{$\begin{array}{c}\text { Reporting Bias } \\
\text { Selective } \\
\text { Reporting }\end{array}$} \\
\hline & & Allocation & & & & \\
\hline RCT Report & $\begin{array}{l}\text { Sequence } \\
\text { Generation }\end{array}$ & Concealment & & & & \\
\hline Bauer et al. 2015 [38] & low & low & low & unclear & Low & low \\
\hline Chanet et al. 2017 [40] & low & low & low & high & Unclear & low \\
\hline Evans et al. 2017 [41] & unclear & low & low & unclear & Low & low \\
\hline $\begin{array}{c}\text { Holwerda et al. } 2019 \\
\text { [42] }\end{array}$ & high & low & low & unclear & Low & unclear \\
\hline Ispoglou et al. 2016 [43] & high & low & unclear & unclear & Low & unclear \\
\hline Kim et al. 2012 [44] & low & low & low & unclear & Low & unclear \\
\hline $\begin{array}{c}\text { Dal Negro et al. } 2012 \\
{[47]}\end{array}$ & high & high & low & high & Unclear & low \\
\hline Leenders et al. 2011 [34] & high & high & low & unclear & Unclear & low \\
\hline $\begin{array}{c}\text { Rondanelli et al. } 2016 \\
\text { [48] }\end{array}$ & unclear & low & low & unclear & Unclear & low \\
\hline $\begin{array}{l}\text { Van de Bool et al. } 2017 \\
\text { [50] }\end{array}$ & low & low & low & unclear & Low & low \\
\hline $\begin{array}{l}\text { Verhoeven et al. } 2009 \\
\text { [51] }\end{array}$ & high & high & low & low & Unclear & low \\
\hline Verlaan et al. 2018 [52] & low & low & low & low & Unclear & unclear \\
\hline Verreijen et al. 2014 [53] & low & low & low & unclear & Low & unclear \\
\hline
\end{tabular}

\section{Discussion}

The loss of muscle mass and strength (sarcopenia) and its functional consequences such as reduced walking speed can occur to a varying degree both as a part of physiological changes during aging [55] or in some pathological conditions increasing the amount of time in bed which in itself can result in catabolism and a decrease in muscle mass [56,57] or patients with chronic diseases such as liver cirrhosis [5,58], COPD [6,7], diabetes [34] and post-stroke patients [54]. Severe sarcopenia is associated with an extremely high rate of disability but not necessarily with body-weight loss, and obese sarcopenic patients appear to have even worse outcomes [59-61].

The best approaches to treat sarcopenia or delay its progression over time are currently based on physical exercise and nutritional supplementation, with resistance training being the most useful tool for effectively preventing [62,63] and treating sarcopenia [64-66]. However, many older people are sedentary and either cannot (social barriers and family support) or do not want to exercise. In these cases, nutritional interventions remain the most promising intervention to delay the appearance of the adverse consequences of sarcopenia such as falls, mobility loss, and a bed-to-sofa lifestyle. Supplementation of the branched-chain amino acid, leucine, or leucine-enriched protein (whey/casein protein) $[28,29,67]$ is one of the most common interventions for treating sarcopenia in older individuals, and several RCTs have been published in the last five years.

Analysis of the trials included in this systematic review showed that these nutritional interventions can improve several aspects of sarcopenia, including muscle strength, lean mass content, and walking speed (although the latter has seldom been investigated) although these effects depend on sarcopenia criteria (ranging from improvement to no effect) and the patients' characteristics. Only one study [39] found a reduction in muscle strength after supplementation with whey protein and casein, although they did not make the reasons for this reduction clear. As possible causes, they cited an insufficient difference in protein intake between groups, a lack of a need for protein-supplementation because of already sufficient dietary protein intake, or the specific characteristics of the patients included in the sample who all had polymyalgia rheumatica. In overall terms, the results of the review suggest that the beneficial effects of leucine-supplementation are more consistent for the improvement in lean mass reported in $63 \%$ of the analysed studies, which is consistent with the physiological action of leucine in muscle metabolism.

Interestingly, the majority of interventions that found an improvement in lean mass after leucine supplementation also co-administered vitamin $\mathrm{D}$ as a part of the nutritional intervention. Vitamin $\mathrm{D}$ 
is increasingly recognised as playing an important role in normal muscle function, and low vitamin D status is associated with an increased risk of falls and proximal weakness [68] and these effects are more prominent in male individuals [69]. In view of these sex-dependent effects, the differential effects of leucine supplementation with or without vitamin D and the measurement of vitamin D as a biological marker of sarcopenia need further research.

In contrast, the sarcopenia criteria related to muscle strength and physical performance are not only mediated by an efficient and proper lean mass, but also by a central nervous system component which forms a neuro-muscular (motor) unit [3,70]. Improvements in neuromuscular activation precede increases in muscle mass in response to resistance training; neuromuscular activation has therefore been proposed as another measure of muscle quality [70]. The fact that in most studies there were no clear parallelism between a positive effect in lean mass improvement accompanied by a positive effect on muscle strength or physical performance confirms that the central nervous system component is necessary for restoring muscular strength in age- and diseases-related sarcopenia is less sensitive to leucine supplementation than lean mass improvement.

With regards to the effects of leucine supplementation in sarcopenia occurring in individuals with some kind of disease, an improvement in muscle strength was observed in COPD patients [47]. Muscle wasting is common in COPD, particularly among those with the emphysema-type, and associated with a high prevalence of osteoporosis, impaired exercise performance, and higher mortality risk [71]. Further RCT should address the effects of leucine supplementation on physical performance, which may definitely be relevant to patients' ability to carry out basic activities of daily life and their quality of life.

A beneficial effect of leucine supplementation co-administered with a program of physical exercise was observed in post-stroke patients for both muscular strength and lean mass [54].

Regarding methodological issues, our analysis highlighted that different sarcopenia evaluation methods have often failed to adequately meet the criteria proposed by the international guidelines $[1,72,73]$. Therefore, future studies should focus on evaluating treatment effects using accepted criteria for defining sarcopenia and to select optimally the features of individuals or patients that could benefit more following an intervention consisting in leucine supplementation [72].

To the best of our knowledge, no published work has investigated the role of comorbidities or polymedication in the effects produced by leucine supplementation and as such further research in this area is clearly warranted. This would enable the selection of patients who could most benefit from supplementation, such as patients with COPD or cirrhosis, because these diseases are classically associated with sarcopenia $[47,49,50]$. To date, the best available evidence suggests that administration of leucine-enriched proteins such as whey/casein protein or an EAA mixture, has beneficial effects for sarcopenic individuals, is well-tolerated, and does not have any serious adverse effects.

Finally, whenever possible, a multidisciplinary approach to treating sarcopenia must be encouraged. This means that besides leucine supplementation, clinicians should prescribe a balanced diet and physical exercise to treat this condition. Finally, our analysis also provides evidence that leucine or leucine-enriched protein supplementation may also have other beneficial effects, such as improving cognitive function [47-49], symptoms of depression [50,52], and quality of life [38,47], which lends further support to the use of this intervention in geriatric populations.

Author Contributions: For research articles with several authors, a short paragraph specifying their individual contributions must be provided. The following statements should be used "conceptualization, F.M.M.-A., R.F.-V. and O.C.; Methodology, O.C.; Formal analysis, F.M.M.-A., R.F.-V.; Data curation, F.M.M.-A., R.F.-V. and O.C.; Writing-original draft preparation F.M.M.-A.; Writing—review and editing, O.C.

Funding: This research received no external funding.

Conflicts of Interest: None of the authors have any financial or personal relationships with other individuals or organisations to disclose. 


\section{References}

1. Cruz-Jentoft, A.J.; Baeyens, J.P.; Bauer, J.M.; Boirie, Y.; Cederholm, T.; Landi, F.; Martin, F.C.; Michel, J.-P.; Rolland, Y.; Schneider, S.M.; et al. Sarcopenia: European consensus on definition and diagnosis: Report of the European Working Group on Sarcopenia in Older People. Age Ageing 2010, 39, 412-423. [CrossRef] [PubMed]

2. Janssen, I. The epidemiology of sarcopenia. Clin. Geriatr. Med. 2011, 27, 355-363. [CrossRef]

3. Tieland, M.; Trouwborst, I.; Clark, B.C. Skeletal muscle performance and ageing. J. Cachexia Sarcopenia Muscle 2018, 9, 3-19. [CrossRef] [PubMed]

4. von Haehling, S.; Morley, J.E.; Anker, S.D. An overview of sarcopenia: Facts and numbers on prevalence and clinical impact. J. Cachexia Sarcopenia Muscle 2010, 1, 129-133. [CrossRef] [PubMed]

5. Kim, G.; Kang, S.H.; Kim, M.Y.; Baik, S.K. Prognostic value of sarcopenia in patients with liver cirrhosis: A systematic review and meta-analysis. PLoS ONE 2017, 12, e0186990. [CrossRef] [PubMed]

6. Bone, A.E.; Hepgul, N.; Kon, S.; Maddocks, M. Sarcopenia and frailty in chronic respiratory disease. Chronic Respir. Dis. 2017, 14, 85-99. [CrossRef] [PubMed]

7. Jones, S.E.; Maddocks, M.; Kon, S.S.C.; Canavan, J.L.; Nolan, C.M.; Clark, A.L.; Polkey, M.I.; Man, W.D.-C. Sarcopenia in COPD: Prevalence, clinical correlates and response to pulmonary rehabilitation. Thorax 2015, 70, 213-218. [CrossRef]

8. Umegaki, H. Sarcopenia and frailty in older patients with diabetes mellitus. Geriatr. Gerontol. Int. 2016, 16, 293-299. [CrossRef]

9. Follis, S.; Cook, A.; Bea, J.W.; Going, S.B.; Laddu, D.; Cauley, J.A.; Shadyab, A.H.; Stefanick, M.L.; Chen, Z. Association Between Sarcopenic Obesity and Falls in a Multiethnic Cohort of Postmenopausal Women. J. Am. Geriatr. Soc. 2018, 66, 2314-2320. [CrossRef]

10. Sim, M.; Prince, R.L.; Scott, D.; Daly, R.M.; Duque, G.; Inderjeeth, C.A.; Zhu, K.; Woodman, R.J.; Hodgson, J.M.; Lewis, J.R. Utility of four sarcopenia criteria for the prediction of falls-related hospitalization in older Australian women. Osteoporos. Int. 2019, 30, 167-176. [CrossRef]

11. Marzetti, E.; Hwang, A.-C.; Tosato, M.; Peng, L.-N.; Calvani, R.; Picca, A.; Chen, L.-K.; Landi, F. Age-related changes of skeletal muscle mass and strength among Italian and Taiwanese older people: Results from the Milan EXPO 2015 survey and the I-Lan Longitudinal Aging Study. Exp. Gerontol. 2018, 102, 76-80. [CrossRef] [PubMed]

12. Srikanthan, P.; Karlamangla, A.S. Muscle mass index as a predictor of longevity in older adults. Am. J. Med. 2014, 127, 547-553. [CrossRef] [PubMed]

13. Cuthbertson, D.J.; Bell, J.A.; Ng, S.Y.; Kemp, G.J.; Kivimaki, M.; Hamer, M. Dynapenic obesity and the risk of incident Type 2 diabetes: The English Longitudinal Study of Ageing. Diabet. Med. 2016, 33, 1052-1059. [CrossRef] [PubMed]

14. Srikanthan, P.; Hevener, A.L.; Karlamangla, A.S. Sarcopenia exacerbates obesity-associated insulin resistance and dysglycemia: Findings from the National Health and Nutrition Examination Survey III. PLoS ONE 2010, 5, e10805. [CrossRef]

15. Deer, R.R.; Dickinson, J.M.; Fisher, S.R.; Ju, H.; Volpi, E. Identifying effective and feasible interventions to accelerate functional recovery from hospitalization in older adults: A randomized controlled pilot trial. Contemp. Clin. Trials 2016, 49, 6-14. [CrossRef]

16. Morais, J.A.; Jacob, K.W.; Chevalier, S. Effects of aging and insulin resistant states on protein anabolic responses in older adults. Exp. Gerontol. 2018, 108, 262-268. [CrossRef]

17. Breen, L.; Phillips, S.M. Skeletal muscle protein metabolism in the elderly: Interventions to counteract the "anabolic resistance" of ageing. Nutr. Metab. (Lond.) 2011, 8, 68. [CrossRef]

18. Paddon-Jones, D.; Campbell, W.W.; Jacques, P.F.; Kritchevsky, S.B.; Moore, L.L.; Rodriguez, N.R.; van Loon, L.J. Protein and healthy aging. Am. J. Clin. Nutr. 2015, 101, 1339S-1345S. [CrossRef]

19. Murphy, C.H.; Oikawa, S.Y.; Phillips, S.M. Dietary Protein to Maintain Muscle Mass in Aging: A Case for Per-meal Protein Recommendations. J. Frailty Aging 2016, 5, 49-58.

20. Bauer, J.; Biolo, G.; Cederholm, T.; Cesari, M.; Cruz-Jentoft, A.J.; Morley, J.E.; Phillips, S.; Sieber, C.; Stehle, P.; Teta, D.; et al. Evidence-based recommendations for optimal dietary protein intake in older people: A position paper from the PROT-AGE Study Group. J. Am. Med. Dir. Assoc. 2013, 14, 542-559. [CrossRef] 
21. Volpi, E.; Campbell, W.W.; Dwyer, J.T.; Johnson, M.A.; Jensen, G.L.; Morley, J.E.; Wolfe, R.R. Is the optimal level of protein intake for older adults greater than the recommended dietary allowance? J. Gerontol. A Biol. Sci. Med. Sci. 2013, 68, 677-681. [CrossRef] [PubMed]

22. De Bandt, J.-P. Leucine and Mammalian Target of Rapamycin-Dependent Activation of Muscle Protein Synthesis in Aging. J. Nutr. 2016, 146, 2616S-2624S. [CrossRef] [PubMed]

23. Casperson, S.L.; Sheffield-Moore, M.; Hewlings, S.J.; Paddon-Jones, D. Leucine supplementation chronically improves muscle protein synthesis in older adults consuming the RDA for protein. Clin. Nutr. 2012, 31, 512-519. [CrossRef] [PubMed]

24. Wall, B.T.; van Loon, L.J.C. Nutritional strategies to attenuate muscle disuse atrophy. Nutr. Rev. 2013, 71, 195-208. [CrossRef]

25. Rieu, I.; Balage, M.; Sornet, C.; Giraudet, C.; Pujos, E.; Grizard, J.; Mosoni, L.; Dardevet, D. Leucine supplementation improves muscle protein synthesis in elderly men independently of hyperaminoacidaemia. J. Physiol. (Lond.) 2006, 575, 305-315. [CrossRef]

26. Balage, M.; Dardevet, D. Long-term effects of leucine supplementation on body composition. Curr. Opin. Clin. Nutr. Metab. Care 2010, 13, 265-270. [CrossRef]

27. van Loon, L.J.C.; Kruijshoop, M.; Menheere, P.P.C.A.; Wagenmakers, A.J.M.; Saris, W.H.M.; Keizer, H.A. Amino acid ingestion strongly enhances insulin secretion in patients with long-term type 2 diabetes. Diabetes Care 2003, 26, 625-630. [CrossRef]

28. Hamarsland, H.; Nordengen, A.L.; Nyvik Aas, S.; Holte, K.; Garthe, I.; Paulsen, G.; Cotter, M.; Børsheim, E.; Benestad, H.B.; Raastad, T. Native whey protein with high levels of leucine results in similar post-exercise muscular anabolic responses as regular whey protein: A randomized controlled trial. J. Int. Soc. Sports Nutr. 2017, 14, 43. [CrossRef]

29. Tang, J.E.; Moore, D.R.; Kujbida, G.W.; Tarnopolsky, M.A.; Phillips, S.M. Ingestion of whey hydrolysate, casein, or soy protein isolate: Effects on mixed muscle protein synthesis at rest and following resistance exercise in young men. J. Appl. Physiol. 2009, 107, 987-992. [CrossRef]

30. Liberati, A.; Altman, D.G.; Tetzlaff, J.; Mulrow, C.; Gøtzsche, P.C.; Ioannidis, J.P.A.; Clarke, M.; Devereaux, P.J.; Kleijnen, J.; Moher, D. The PRISMA statement for reporting systematic reviews and meta-analyses of studies that evaluate healthcare interventions: Explanation and elaboration. BMJ 2009, 339, b2700. [CrossRef]

31. Higgins, J.P.T.; Altman, D.G.; Gøtzsche, P.C.; Jüni, P.; Moher, D.; Oxman, A.D.; Savovic, J.; Schulz, K.F.; Weeks, L.; Sterne, J.A.C.; et al. The Cochrane Collaboration's tool for assessing risk of bias in randomised trials. BMJ 2011, 343, d5928. [CrossRef] [PubMed]

32. Kemmler, W.; Weissenfels, A.; Teschler, M.; Willert, S.; Bebenek, M.; Shojaa, M.; Kohl, M.; Freiberger, E.; Sieber, C.; von Stengel, S. Whole-body electromyostimulation and protein supplementation favorably affect sarcopenic obesity in community-dwelling older men at risk: The randomized controlled FranSO study. Clin. Interv. Aging 2017, 12, 1503-1513. [CrossRef] [PubMed]

33. Kramer, I.F.; Verdijk, L.B.; Hamer, H.M.; Verlaan, S.; Luiking, Y.C.; Kouw, I.W.K.; Senden, J.M.; van Kranenburg, J.; Gijsen, A.P.; Bierau, J.; et al. Both basal and post-prandial muscle protein synthesis rates, following the ingestion of a leucine-enriched whey protein supplement, are not impaired in sarcopenic older males. Clin. Nutr. 2017, 36, 1440-1449. [CrossRef] [PubMed]

34. Leenders, M.; Verdijk, L.B.; van der Hoeven, L.; van Kranenburg, J.; Hartgens, F.; Wodzig, W.K.W.H.; Saris, W.H.M.; van Loon, L.J.C. Prolonged leucine supplementation does not augment muscle mass or affect glycemic control in elderly type 2 diabetic men. J. Nutr. 2011, 141, 1070-1076. [CrossRef] [PubMed]

35. Bukhari, S.S.I.; Phillips, B.E.; Wilkinson, D.J.; Limb, M.C.; Rankin, D.; Mitchell, W.K.; Kobayashi, H.; Greenhaff, P.L.; Smith, K.; Atherton, P.J. Intake of low-dose leucine-rich essential amino acids stimulates muscle anabolism equivalently to bolus whey protein in older women at rest and after exercise. Am. J. Physiol. Endocrinol. Metab. 2015, 308, E1056-E1065. [CrossRef] [PubMed]

36. Devries, M.C.; McGlory, C.; Bolster, D.R.; Kamil, A.; Rahn, M.; Harkness, L.; Baker, S.K.; Phillips, S.M. Protein leucine content is a determinant of shorter- and longer-term muscle protein synthetic responses at rest and following resistance exercise in healthy older women: A randomized, controlled trial. Am. J. Clin. Nutr. 2018, 107, 217-226. [CrossRef] [PubMed]

37. Abe, S.; Ezaki, O.; Suzuki, M. Medium-Chain Triglycerides in Combination with Leucine and Vitamin D Increase Muscle Strength and Function in Frail Elderly Adults in a Randomized Controlled Trial. J. Nutr. 2016, 146, 1017-1026. [CrossRef] 
38. Bauer, J.M.; Verlaan, S.; Bautmans, I.; Brandt, K.; Donini, L.M.; Maggio, M.; McMurdo, M.E.T.; Mets, T.; Seal, C.; Wijers, S.L.; et al. Effects of a vitamin D and leucine-enriched whey protein nutritional supplement on measures of sarcopenia in older adults, the PROVIDE study: A randomized, double-blind, placebo-controlled trial. J. Am. Med. Dir. Assoc. 2015, 16, 740-747. [CrossRef]

39. Björkman, M.P.; Pilvi, T.K.; Kekkonen, R.A.; Korpela, R.; Tilvis, R.S. Similar effects of leucine rich and regular dairy products on muscle mass and functions of older polymyalgia rheumatica patients: A randomized crossover trial. J. Nutr. Health Aging 2011, 15, 462-467. [CrossRef]

40. Chanet, A.; Verlaan, S.; Salles, J.; Giraudet, C.; Patrac, V.; Pidou, V.; Pouyet, C.; Hafnaoui, N.; Blot, A.; Cano, N.; et al. Supplementing Breakfast with a Vitamin D and Leucine-Enriched Whey Protein Medical Nutrition Drink Enhances Postprandial Muscle Protein Synthesis and Muscle Mass in Healthy Older Men. J. Nutr. 2017, 147, 2262-2271. [CrossRef]

41. Evans, M.; Guthrie, N.; Pezzullo, J.; Sanli, T.; Fielding, R.A.; Bellamine, A. Efficacy of a novel formulation of L-Carnitine, creatine, and leucine on lean body mass and functional muscle strength in healthy older adults: A randomized, double-blind placebo-controlled study. Nutr. Metab. (Lond.) 2017, 14, 7. [CrossRef] [PubMed]

42. Holwerda, A.M.; Paulussen, K.J.M.; Overkamp, M.; Goessens, J.P.B.; Kramer, I.-F.; Wodzig, W.K.W.H.; Verdijk, L.B.; de Groot, L.C.P.G.M.; van Loon, L.J.C. Leucine co-ingestion augments the muscle protein synthetic response to the ingestion of $15 \mathrm{~g}$ protein following resistance exercise in older men. Am. J. Physiol. Endocrinol. Metab. 2019. [CrossRef] [PubMed]

43. Ispoglou, T.; White, H.; Preston, T.; McElhone, S.; McKenna, J.; Hind, K. Double-blind, placebo-controlled pilot trial of L-Leucine-enriched amino-acid mixtures on body composition and physical performance in men and women aged 65-75 years. Eur. J. Clin. Nutr. 2016, 70, 182-188. [CrossRef] [PubMed]

44. Kim, H.K.; Suzuki, T.; Saito, K.; Yoshida, H.; Kobayashi, H.; Kato, H.; Katayama, M. Effects of exercise and amino acid supplementation on body composition and physical function in community-dwelling elderly Japanese sarcopenic women: A randomized controlled trial. J. Am. Geriatr. Soc. 2012, 60, 16-23. [CrossRef]

45. Kirk, B.; Mooney, K.; Amirabdollahian, F.; Khaiyat, O. Exercise and Dietary-Protein as a Countermeasure to Skeletal Muscle Weakness: Liverpool Hope University-Sarcopenia Aging Trial (LHU-SAT). Front. Physiol. 2019, 10, 445. [CrossRef]

46. Kouw, I.W.; Holwerda, A.M.; Trommelen, J.; Kramer, I.F.; Bastiaanse, J.; Halson, S.L.; Wodzig, W.K.; Verdijk, L.B.; van Loon, L.J. Protein Ingestion before Sleep Increases Overnight Muscle Protein Synthesis Rates in Healthy Older Men: A Randomized Controlled Trial. J. Nutr. 2017, 147, 2252-2261. [CrossRef]

47. Dal Negro, R.W.; Testa, A.; Aquilani, R.; Tognella, S.; Pasini, E.; Barbieri, A.; Boschi, F. Essential amino acid supplementation in patients with severe COPD: A step towards home rehabilitation. Monaldi Arch. Chest Dis. 2012, 77, 67-75. [CrossRef]

48. Rondanelli, M.; Klersy, C.; Terracol, G.; Talluri, J.; Maugeri, R.; Guido, D.; Faliva, M.A.; Solerte, B.S.; Fioravanti, M.; Lukaski, H.; et al. Whey protein, amino acids, and vitamin D supplementation with physical activity increases fat-free mass and strength, functionality, and quality of life and decreases inflammation in sarcopenic elderly. Am. J. Clin. Nutr. 2016, 103, 830-840. [CrossRef]

49. Soriano, G.; Román, E.; Torrades, M.T.; Cárdenas, G.; Córdoba, J.; Blanco, M.J.N.; Nieto, J.C.; Vidal, S.; Villanueva, C.; Ambrós, H.B.; et al. Estudio del beneficio de un programa de ejercicio físico y suplementos de aminoácidos ramificados en la dieta dirigido a pacientes con cirrosis hepática. Trauma 2013, 24, 6-11.

50. van de Bool, C.; Rutten, E.P.A.; van Helvoort, A.; Franssen, F.M.E.; Wouters, E.F.M.; Schols, A.M.W.J. A randomized clinical trial investigating the efficacy of targeted nutrition as adjunct to exercise training in COPD. J. Cachexia Sarcopenia Muscle 2017, 8, 748-758. [CrossRef]

51. Verhoeven, S.; Vanschoonbeek, K.; Verdijk, L.B.; Koopman, R.; Wodzig, W.K.W.H.; Dendale, P.; van Loon, L.J.C. Long-term leucine supplementation does not increase muscle mass or strength in healthy elderly men. Am. J. Clin. Nutr. 2009, 89, 1468-1475. [CrossRef] [PubMed]

52. Verlaan, S.; Maier, A.B.; Bauer, J.M.; Bautmans, I.; Brandt, K.; Donini, L.M.; Maggio, M.; McMurdo, M.E.T.; Mets, T.; Seal, C.; et al. Sufficient levels of 25-hydroxyvitamin D and protein intake required to increase muscle mass in sarcopenic older adults-The PROVIDE study. Clin. Nutr. 2018, 37, 551-557. [CrossRef] [PubMed] 
53. Verreijen, A.M.; Verlaan, S.; Engberink, M.F.; Swinkels, S.; de Vogel-van den Bosch, J.; Weijs, P.J.M. A high whey protein-, leucine-, and vitamin D-enriched supplement preserves muscle mass during intentional weight loss in obese older adults: A double-blind randomized controlled trial. Am. J. Clin. Nutr. 2015, 101, 279-286. [CrossRef] [PubMed]

54. Yoshimura, Y.; Bise, T.; Shimazu, S.; Tanoue, M.; Tomioka, Y.; Araki, M.; Nishino, T.; Kuzuhara, A.; Takatsuki, F. Effects of a leucine-enriched amino acid supplement on muscle mass, muscle strength, and physical function in post-stroke patients with sarcopenia: A randomized controlled trial. Nutrition 2019, 58, 1-6. [CrossRef] [PubMed]

55. Beaudart, C.; Zaaria, M.; Pasleau, F.; Reginster, J.-Y.; Bruyère, O. Health Outcomes of Sarcopenia: A Systematic Review and Meta-Analysis. PLoS ONE 2017, 12, e0169548. [CrossRef]

56. Cerri, A.P.; Bellelli, G.; Mazzone, A.; Pittella, F.; Landi, F.; Zambon, A.; Annoni, G. Sarcopenia and malnutrition in acutely ill hospitalized elderly: Prevalence and outcomes. Clin. Nutr. 2015, 34, 745-751. [CrossRef]

57. Fielding, R.A.; Vellas, B.; Evans, W.J.; Bhasin, S.; Morley, J.E.; Newman, A.B.; Abellan van Kan, G.; Andrieu, S.; Bauer, J.; Breuille, D.; et al. Sarcopenia: An undiagnosed condition in older adults. Current consensus definition: Prevalence, etiology, and consequences. International working group on sarcopenia. J. Am. Med. Dir. Assoc. 2011, 12, 249-256. [CrossRef]

58. Sinclair, M.; Gow, P.J.; Grossmann, M.; Angus, P.W. Review article: Sarcopenia in cirrhosis-Aetiology, implications and potential therapeutic interventions. Aliment. Pharmacol. Ther. 2016, 43, 765-777. [CrossRef]

59. Choi, K.M. Sarcopenia and sarcopenic obesity. Korean J. Intern. Med. 2016, 31, 1054-1060. [CrossRef]

60. Poggiogalle, E.; Migliaccio, S.; Lenzi, A.; Donini, L.M. Treatment of body composition changes in obese and overweight older adults: Insight into the phenotype of sarcopenic obesity. Endocrine 2014, 47, 699-716. [CrossRef]

61. Morley, J.E. Frailty and Sarcopenia: The New Geriatric Giants. Rev. Investig. Clin. 2016, 68, 59-67.

62. Makanae, Y.; Fujita, S. Role of Exercise and Nutrition in the Prevention of Sarcopenia. J. Nutr. Sci. Vitaminol. 2015, 61, S125-S127. [CrossRef] [PubMed]

63. Coelho-Júnior, H.J.; de Oliveira Gonçalvez, I.; Sampaio, R.A.C.; Sewo Sampaio, P.Y.; Cadore, E.L.; Izquierdo, M.; Marzetti, E.; Uchida, M.C. Periodized and non-periodized resistance training programs on body composition and physical function of older women. Exp. Gerontol. 2019, 121, 10-18. [CrossRef] [PubMed]

64. Osuka, Y.; Kojima, N.; Wakaba, K.; Miyauchi, D.; Tanaka, K.; Kim, H. Effects of resistance training and/or beta-hydroxy-beta-methylbutyrate supplementation on muscle mass, muscle strength and physical performance in older women with reduced muscle mass: Protocol for a randomised, double-blind, placebo-controlled trial. BMJ Open 2019, 9, e025723. [CrossRef] [PubMed]

65. Tsuzuku, S.; Kajioka, T.; Sakakibara, H.; Shimaoka, K. Slow movement resistance training using body weight improves muscle mass in the elderly: A randomized controlled trial. Scand. J. Med. Sci. Sports 2018, 28, 1339-1344. [CrossRef]

66. Komar, B.; Schwingshackl, L.; Hoffmann, G. Effects of leucine-rich protein supplements on anthropometric parameter and muscle strength in the elderly: A systematic review and meta-analysis. J. Nutr. Health Aging 2015, 19, 437-446. [CrossRef]

67. Antoniak, A.E.; Greig, C.A. The effect of combined resistance exercise training and vitamin D3 supplementation on musculoskeletal health and function in older adults: A systematic review and meta-analysis. BMJ Open 2017, 7, e014619. [CrossRef]

68. Spira, D.; Buchmann, N.; König, M.; Rosada, A.; Steinhagen-Thiessen, E.; Demuth, I.; Norman, K. Sex-specific differences in the association of vitamin D with low lean mass and frailty: Results from the Berlin Aging Study II. Nutrition 2019, 62, 1-6. [CrossRef]

69. McGregor, R.A.; Cameron-Smith, D.; Poppitt, S.D. It is not just muscle mass: A review of muscle quality, composition and metabolism during ageing as determinants of muscle function and mobility in later life. Longev. Healthspan 2014, 3, 9. [CrossRef]

70. Häkkinen, K.; Kraemer, W.J.; Kallinen, M.; Linnamo, V.; Pastinen, U.M.; Newton, R.U. Bilateral and unilateral neuromuscular function and muscle cross-sectional area in middle-aged and elderly men and women. $J$. Gerontol. A Biol. Sci. Med. Sci. 1996, 51, B21-B29. [CrossRef] 
71. Schols, A.M.; Ferreira, I.M.; Franssen, F.M.; Gosker, H.R.; Janssens, W.; Muscaritoli, M.; Pison, C.; Rutten-van Mölken, M.; Slinde, F.; Steiner, M.C.; et al. Nutritional assessment and therapy in COPD: A European Respiratory Society statement. Eur. Respir. J. 2014, 44, 1504-1520. [CrossRef] [PubMed]

72. Cruz-Jentoft, A.J.; Bahat, G.; Bauer, J.; Boirie, Y.; Bruyère, O.; Cederholm, T.; Cooper, C.; Landi, F.; Rolland, Y.; Sayer, A.A.; et al. Sarcopenia: Revised European consensus on definition and diagnosis. Age Ageing 2019, 48, 16-31. [CrossRef] [PubMed]

73. Studenski, S.A.; Peters, K.W.; Alley, D.E.; Cawthon, P.M.; McLean, R.R.; Harris, T.B.; Ferrucci, L.; Guralnik, J.M.; Fragala, M.S.; Kenny, A.M.; et al. The FNIH sarcopenia project: Rationale, study description, conference recommendations, and final estimates. J. Gerontol. A Biol. Sci. Med. Sci. 2014, 69, 547-558. [CrossRef] [PubMed]

(C) 2019 by the authors. Licensee MDPI, Basel, Switzerland. This article is an open access article distributed under the terms and conditions of the Creative Commons Attribution (CC BY) license (http://creativecommons.org/licenses/by/4.0/). 